DOI: $10.5937 /$ halo $27-32452$

UDC: $613.953 .11(497.11) " 2018 "$

Savić N, i sar. Mothers' knowledge of successful breastfeeding. Halo 194. 2021; 27(2):58-62.

Rad primljen: 28.05.2021.

Prihvaćen: $\quad 01.06 .2021$

\section{Correspodence to:}

Nikola Savić

Železnička 5

14000 Valjevo

Srbija,

E-mail:

nikolasavicvzs@gmail.com

Mob. tel: +381645267057
ORIGINAL ARTICLES

\section{ASSESSMENT OF MOTHERS' KNOWLEDGE AND EVALUATION OF OBSTACLES TO SUCCESSFUL BREASTFEEDING}

\author{
Nikola SAVIĆ ${ }^{l, 2}$, Marijana MILOŠEVIĆ ${ }^{1,2}$, Marija MLADENOVIĆ ${ }^{2,3}$, Zoran JOKIĆ ${ }^{2,4}$, \\ Slađana ANĐELIĆ $C^{2,5}$
}

${ }^{1}$ Medical school "Dr Miša Pantić", Valjevo, Serbia. ${ }^{2}$ Faculty of Health and Business Studies, Singidunum University, Valjevo, Serbia. ${ }^{3}$ Valjevo General Hospital, Valjevo, Serbia. ${ }^{4}$ Polyclinic Jokić, Valjevo, Serbia. ${ }^{5}$ City Institute for Emergency Medical Aid Belgrade, Belgrade, Serbia

\begin{abstract}
Introduction/Objective A healthy diet is a basic prerequisite for a healthy child. Numerous studies have proven the importance of breastfeeding, which has many advantages. Breast milk is the best choice of food for a newborn. Healthcare professionals, doctors and nurses, play a key role in shaping a mother's attitude towards breastfeeding, as well as helping her overcome barriers to successful breastfeeding. To examine the level of knowledge mothers have about the importance of proper nutrition and breastfeeding of a newborn and to evaluate any obstacles to successful breastfeeding.

Methods The first part of the research is designed as a cross-sectional study. As a research instrument, a questionnaire was constructed to assess the mothers' level of knowledge about the importance of breastfeeding. In the second part of the research, a telephone survey was conducted after the mothers and babies were discharged from the hospital, and the mothers were asked questions about any obstacles they may have encountered to successful breastfeeding. The study included a sample of 47 women. The study was conducted in the Valjevo General Hospital from June to August 2018. Participation in the study was voluntary and anonymous and the research was approved by the Ethics Committee of the institution. Results Descriptive statistic methods were used to analyse the results. Respondents ranged in age from 21 to 40, the largest number of women were between 21 and 25 years old (57\%), $88 \%$ of children received a grade 9 at birth, $10 \%$ of the respondents attended parenting school, $78 \%$ of the women started breastfeeding the very next day after delivery and most believed that they had been successfully trained to breastfeed in the maternity ward. Seven days after discharge from the hospital, $7 \%$ of women did not breastfeed and the most common obstacles to successful breastfeeding were cracked nipples (35\%).

Conclusion The results of the research indicate the need for a greater degree of education of future mothers about the importance of breastfeeding and proper breastfeeding techniques. It is necessary to carry out health education work at all levels of health care to minimize obstacles to natural nutrition.
\end{abstract}

Keywords: Breastfeeding, natural nutrition, nutrition, infant.

\section{INTRODUCTION}

Lactation or milk production is a consequence of the action of prolactin, a hormone secreted by the anterior pituitary gland. Prolactin enables the production of milk in the mammary glands. The physiological course of breastfeeding is provided by the breast, which produces and releases milk, and the newborn, who can extract the milk from the breast through the action of sucking [1]. Breastfeeding is of great importance for the proper growth and development of the child. The American Academy of Pediatrics confirms its recommendations and emphasizes the importance of breastfeeding in the first six months of a child's life, as well as continued breastfeeding even after that period parallel to the introduction of appropriate foods [2]. Based on studies from Belarus, Iran and Nigeria, it is concluded that children who continue breastfeeding after six months or more have a significantly reduced risk of gastrointestinal and respiratory infections [3]. Breast milk contains all the necessary nutrients that a newborn needs and replaceable elements that affect the baby's immune system. Contraindications to breastfeeding are rare [4,5]. Successful breastfeeding is influenced by various factors. Social variables depend on the amount of time the mother spends with the child, family support and professional support. Maternal beliefs and attitudes towards breastfeeding are psychological variables that have a huge impact. Professional support by health workers, through education and health education work, has shown exceptional results in many studies, but also in practice [6]. Health education of pregnant women and mothers on the topic of breastfeeding is of key importance. The health educator should work to combine several methods of education (communication strategies, training methods, organizational methods) to increase the quality of health education [7]. 
It is necessary to inform new mothers about the current and long-term benefits of breastfeeding [8]. Healthcare educators who work with new mothers should enable them to acquire the highest possible degree of independence and knowledge of proper breastfeeding techniques, so they can persevere in the event of possible obstacles [9]. Numerous studies indicate that breastfeeding has a positive effect not only on the health of the child but also on the health of the mother. Breastfeeding establishes a connection between mother and child, creating a feeling of closeness and connection $[10,11]$. Doctors and nurses have a fundamental role in forming the correct attitude towards breastfeeding [12]. Breastfeeding is a permanent investment in a child's physical, mental and social abilities and has a positive health economics impact [13]. Short-term natural nutrition, early supplementation and milk selection could be determining factors in the development and manifestation of anaemia [14]. Increasing breastfeeding rates in countries with high mortality could prevent 1.3 to 1.45 million child deaths [15]. Breast milk is the safest and ideal food for a child, but it can also cause infant health disorders if the mother takes certain medications, eats improperly or does not give up her bad habits, such as consuming alcohol or narcotics [16]. Many factors can be obstacles to successful breastfeeding, such as cracked nipples, mastitis, retracted nipples and others $[1,17]$.

\section{OBJECTIVE}

This study aims to examine the awareness of new mothers about the importance of proper nutrition and breastfeeding to the newborn, as well as evaluation of obstacles to successful breastfeeding. Research on this topic is of great importance and can help improve professional activity and health education work.

\section{METHODS}

The first part of the research is designed in the form of a cross-sectional study. As a research instrument, a questionnaire for new mothers was constructed to assess their level of information about the importance of breastfeeding. In the second part of the research, a telephone survey of new mothers was conducted seven days after discharge from the maternity hospital, and respondents were asked about the presence of obstacles to successful breastfeeding, such as cracked nipples, mastitis, retracted nipples, insufficient motivation to breastfeed and others. The study included a sample of 47 women and was conducted at the General Hospital Valjevo from June to August 2018. Participation in the study was voluntary and anonymous and the research was approved by the Ethics Committee of the institution. The criterion for including a mother in the study was her consent to participate in the research and consent to answer all the questions. The criterion for not including new mothers was that they did not want to participate in the research. The criterion for excluding respondents from the research was if they had omitted to give answers to all the questions in the questionnaire. Before the start of the research, the respondents received the necessary information regarding the study in oral and written form. The mothers were given instructions needed to correctly complete the questionnaire. The questionnaires were distributed and data collected personally by the researchers. Statistical data processing included methods of descriptive statistics. The obtained results were presented in tables and graphs.

\section{RESULTS}

In the analyzed sample, the largest number of mothers were between the ages of 21 and 25 (47\%). The lowest number of women were over 40 years of age (2\%). The largest number of respondents lived in urban areas $(78 \%)$. Among the women included in the study, the largest number had secondary education (82\%), with much smaller percentages of mothers with higher education $(8 \%)$ and primary education $(10 \%)$. The largest number of respondents who participated in the survey were employed (59\%). There were $33 \%$ of unemployed mothers, while only $8 \%$ of the mothers were occasionally (seasonally) employed. The largest number of mothers were married $(92 \%)$, while $8 \%$ of the women were out of wedlock. The largest number of respondents lived with their husbands $73 \%$, while $2 \%$ of the women lived alone. The largest number of respondents gave birth naturally $(67 \%)$, while $33 \%$ gave birth by caesarean section. The largest number of children received a grade of 9 at birth $(88 \%)$ and the largest number of women did not attend parenting classes (89\%) (Table 1).

Distribution of multiparous respondents according to whether they breastfed older children is shown in Figure 1.

In the examined sample, a total of 30 women had already given birth (64\%). Most mothers breastfed their older children $(\mathrm{N}=23 ; 77 \%)$. In the examined sample, mothers showed a high level of information about the importance of breastfeeding and the benefits of natural nutrition (Table 2).

Seven days after discharge from the maternity hospital, a telephone survey was conducted for mothers who had agreed to participate in the study to evaluate the presence of possible obstacles to successful breastfeeding (Figure 2).

Most women did not have any problems related to breastfeeding $(\mathrm{N}=25 ; 53 \%)$. The most common obstacle to successful breastfeeding was the appearance of sores/bruises $(\mathrm{N}=16 ; 35 \%)$. 
Table 1. Socio-demographic and general data regarding the mothers

\begin{tabular}{|c|c|c|}
\hline \multicolumn{2}{|c|}{ Criteria for distribution of respondents } & $\mathbf{N}-\%$ \\
\hline \multirow[t]{4}{*}{ Age of the mother } & Under $18,18-21$. year & $0-0$ \\
\hline & from 21 to 25 & $27-57$ \\
\hline & from 25 to 35 & $19-41$ \\
\hline & from 35 to 45 and more & $1-2$ \\
\hline \multirow[t]{2}{*}{ Living environment } & Urban environment & $37-78$ \\
\hline & Rural environment & $10-22$ \\
\hline \multirow{3}{*}{$\begin{array}{l}\text { Professional } \\
\text { qualifications }\end{array}$} & Primary School & $5-10$ \\
\hline & High School & $38-82$ \\
\hline & University education & $4-8$ \\
\hline \multirow{3}{*}{ Employment } & Yes & $27-59$ \\
\hline & No & $16-33$ \\
\hline & Periodically & $4-8$ \\
\hline \multirow[t]{2}{*}{ Marriage } & Marriage & $43-92$ \\
\hline & Extramarital union & $4-8$ \\
\hline \multirow{2}{*}{ Type of birth } & Natural & $31-67$ \\
\hline & Caesarean section & $16-33$ \\
\hline \multirow{2}{*}{$\begin{array}{l}\begin{array}{l}\text { Assessment of the } \\
\text { child at birth }\end{array} \\
\end{array}$} & 8 & $6-22$ \\
\hline & 9 & $41-88$ \\
\hline \multirow{2}{*}{$\begin{array}{l}\text { Distribution of } \\
\text { respondents according } \\
\text { to whether they } \\
\text { attended parenting } \\
\text { school }\end{array}$} & Yes & $5-11$ \\
\hline & No & $42-89$ \\
\hline \multirow{3}{*}{ First breastfeeding } & Delivery room & $9-20$ \\
\hline & The day after the birth & $37-78$ \\
\hline & A few days later & $1-2$ \\
\hline
\end{tabular}

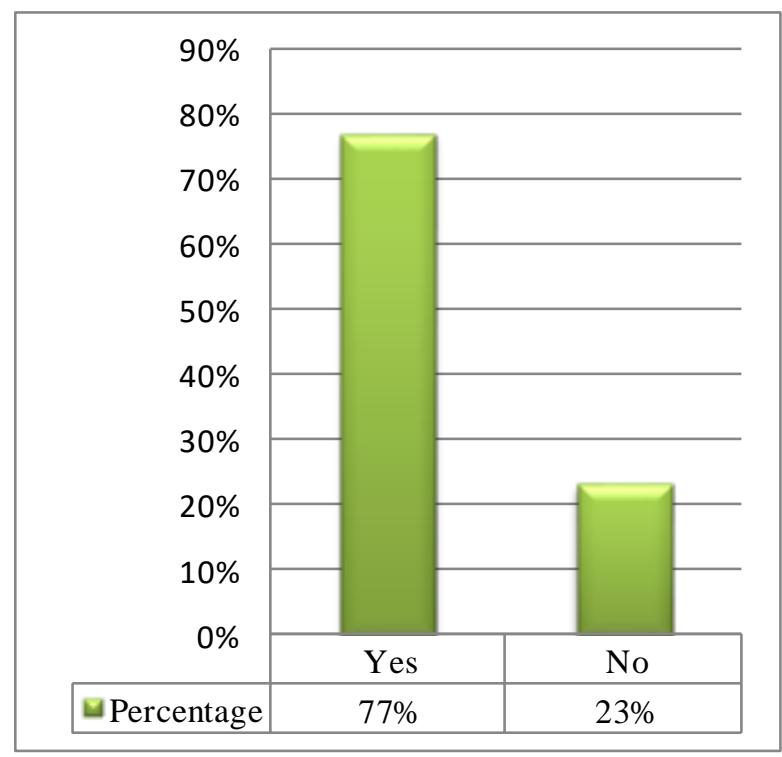

Figure 1. Distribution of respondents according to whether they breastfed their older child/children
Table 2. Informing mothers about the importance of breastfeeding

\begin{tabular}{|l|l|c|}
\hline \multicolumn{2}{|l|}{ Criteria for the distribution of respondents } & N - \% \\
\hline $\begin{array}{l}\text { Breast milk is the healthiest } \\
\text { food option in the first } \\
\text { months of a child's life }\end{array}$ & Yes & $47-100$ \\
\cline { 2 - 3 } & No & $0-0$ \\
\hline $\begin{array}{l}\text { Breastfed babies are } \\
\text { healthier than formula-fed } \\
\text { babies }\end{array}$ & Yes & $41-88$ \\
\cline { 2 - 3 } & No & $6-12$ \\
\hline $\begin{array}{l}\text { It is necessary to breastfeed } \\
\text { the baby for at least } 6 \\
\text { months }\end{array}$ & Yes & $33-70$ \\
\cline { 2 - 3 } $\begin{array}{l}\text { No } \\
\text { effect on a woman's health }\end{array}$ & I do not know & $5-10$ \\
\cline { 2 - 3 } & No & $28-60$ \\
\cline { 2 - 3 } & I do not know & $4-8$ \\
\hline $\begin{array}{l}\text { Breastfeeding should be } \\
\text { stopped only in consultation } \\
\text { with a doctor }\end{array}$ & Yes & $46-98$ \\
\cline { 2 - 3 } & No & $1-2$ \\
\hline
\end{tabular}

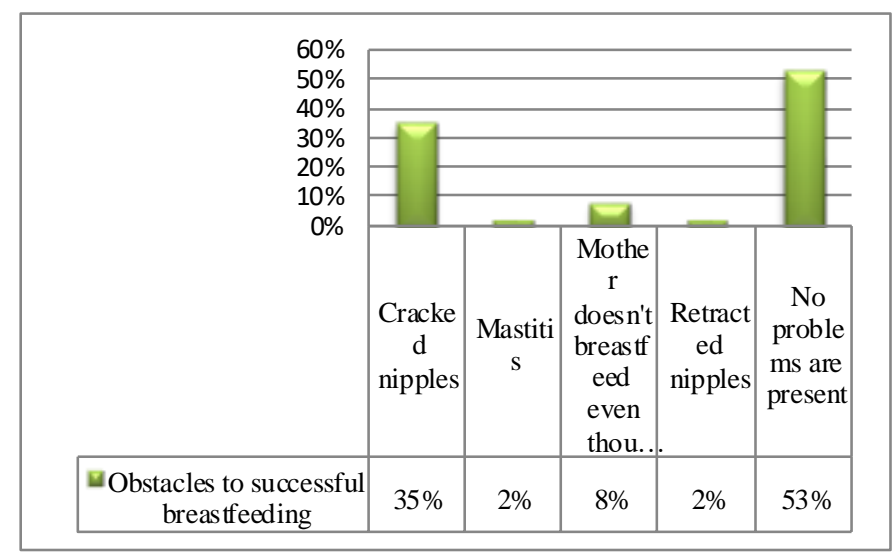

Figure 2. Presence of obstacles to successful breastfeeding

\section{DISCUSSION}

Numerous research, as well as practice, prove that breastfeeding is beneficial for the health of the child in many ways. Published evidence-based studies confirm the impact of breastfeeding on the growth and development of the newborn but also identifies the risks of not breastfeeding [2]. It is necessary to influence future mothers to form the correct attitude towards breastfeeding, to promote breastfeeding and intervene with health education. It is necessary to put more work into informing women about the benefits of breastfeeding and the impact of natural nutrition on the health potential of the child, its body weight, immunity, cognitive abilities, dental caries and other factors [3]. 
In the study we conducted, the largest number of mothers were informed about the basic aspects related to the natural nutrition of the newborn. Women who found themselves in the observed sample knew that breast milk was an ideal diet for a newborn in the first days and months of life. Numerous obstacles to successful breastfeeding have been identified and evaluated, the most dominant of which is the occurrence of sores and the lack of motivation in women to persevere in the natural nutrition of the child. It is commendable that more than half of the women in the observed sample (53\%) have no obstacles to successful breastfeeding after discharge from the maternity hospital. Breastfeeding has advantages not only for the child but also for the mother. This is the main reason that it is often stated in the modern obstetric literature that breastfeeding is the last phase of childbirth [5,17].

\section{CONCLUSION}

Regardless of these results, it is necessary to intensify health education work at all levels of health care and refer pregnant women to counselling and parenting classes, where they would receive useful information.

Conflict of interest: none declared.

\section{REFERENCES}

1. Živanović V. Zdravstvena nega u ginekologiji i akušerstvu. Beograd: Visoka zdravstvena škola. 2012; str. 273-285.

2. Geddes D, Perrella S. Breastfeeding and Human Lactation. Nutrients. 2019;11(4):802.

3. Westerfield KL, Koenig K, Oh R. Breastfeeding: Common Questions and Answers. Am Fam Physician. 2018;98(6):368-373.

4. Wambach K, Spencer B. Breastfeeding and human lactation. 6th ed. Denton, Texsas, USA: Jones\&Bartlett learning. 2019; p. 157-177.

5. Ares Segura S, Arena Ansótegui J, Marta DíazGómez N. The importance of maternal nutrition during breastfeeding: Do breastfeeding mothers need nutritional supplements?. Anales de Pediatría (English Edition). 2016;84(6):347.1347.e7.

6. McFadden A, Gavine A, Renfrew M, Wade A, Buchanan P, Taylor J et al. Support for healthy breastfeeding mothers with healthy term babies. Cochrane Database of Systematic Reviews. 2017; 2(2):CD001141.

7. Kekuš D. Zdravstveno vaspitanje. Beograd: D. Kekuš; 2009; str. 51-198.

8. Taylor J, Boies E. Membership in the Academy of Breastfeeding Medicine: What Are the Benefits?. Breastfeeding Medicine. 2016; 11(9): 490-491.
9. Blyth R, Creedy D, Dennis C, Moyle W, Pratt J, De Vries S. Effect of Maternal Confidence on Breastfeeding Duration: An Application of Breastfeeding Self-Efficacy Theory. Birth. 2002; 29(4):278-284.

10. Weaver J, Schofield T, Papp L. Breastfeeding duration predicts greater maternal sensitivity over the next decade. Developmental Psychology. 2018;54(2):220-227.

11. Milankov O. Dojenje kroz vekove. Medicinski pregled. 2018; 71(5-6):151-156.

12. Cogburn G, Ketner M. The North Carolina Lactation Educator Training Program: A Report at 20 Years. Journal of Human Lactation. 2017; 33(4):736-739.

13. Hansen K. Breastfeeding: a smart investment in people and in economies. The Lancet. 2016; 387(10017):416.

14. Milankov O, Bjelica M, Savić R. Kojom vrstom mleka je moguće prevenirati nastanak sideropenijske anemije kod odojčadi komparativna studija. Medicinski pregled. 2014; 67(5-6):167-171.

15. Šrek A. Uvođenje nemlečne ishrane $u$ odojčadskom uzrastu - nove preporuke. Hrana i ishrana. 2011; 52(1):11-14.

16. Greiner T. Alcohol and Breastfeeding, a review of the issues. World Nutrition. 2019;10(1):63-88.

17. Novakov Mikić A, Vejnović T. Akušerstvo. Novi Sad: Univerzitet u Novom Sadu, Medicinski fakultet; 2020. 293-294. 
ORIGINALNI RAD

PROCENA ZNANJA MAJKI I EVALUACIJA PREPREKA ZA USPEŠNO DOJENJE

Nikola SAVIĆ ${ }^{1,2}$, Marijana MILOŠEVIĆ ${ }^{1,2}$, Marija MLADENOVIĆ ${ }^{2,3}$, Zoran JOKIĆ ${ }^{2,4}$, Slađana ANĐELIĆ ${ }^{2,5}$

${ }^{1}$ Medicinska škola "Dr Miša Pantić", Valjevo, Srbija. ${ }^{2}$ Fakultet poslovnih i zdravstvenih studija Univerziteta Singidunum, Valjevo, Srbija. ${ }^{3}$ Opšta bolnica Valjevo, Srbija. ${ }^{4}$ Poliklinika Jokić, Valjevo, Srbija. ${ }^{5}$ Gradski zavod za hitnu medicinsku pomoć, Beograd, Srbija

\section{SAŽETAK}

Uvod/Cilj Zdrava ishrana predstavlja osnovni preduslov za zdravlje deteta. Brojna istraživanja dokazala su važnost dojenja, koje ima niz prednosti. Majčino mleko predstavlja najpovoljniju hranu za novorodjenče. Zdravstveni radnici, lekari i medicinske sestre, imaju ključnu ulogu u formiranju pravilnih stavova majki prema dojenju i pružanju pomoći u prevazilaženju barijera za uspešno dojenje. Cilj rada je ispitati znanja porodilja o značaju pravilne ishrane novorođenčeta i dojenju, evaluirati prepreke za uspešno dojenje.

Metod rada Prvi deo istraživanja dizajniran je u vidu studije preseka. Kao instrument istraživanja, konstruisan je upitnik za porodilje kojim se procenjuje njihov stepen informisanosti o značaju dojenja, u drugom delu istraživanja sprovedeno je telefonsko anketiranje porodilja nakon otpusta iz bolnice, ispitanicima su postavljena pitanja u vezi sa prisustvom prepreka za uspešno dojenje. Ispitivanjem je obuhvaćen uzorak od 47 žena, studija je sprovedena u OB Valjevo u vremenskom periodu jun-avgust 2018. godine. Učešće u studiji je bilo dobrovoljno i anonimno, istraživanje je odobreno od Etičkog odbora ustanove.

Rezultati U analizi rezultata korišćene su metode deskriptivne statistike. Ispitanice su bile od 21 do 40 godine starosti, najveći broj žena je starosti od 21 do 25 godina (57\%), 88\% dece na rođenju je dobilo ocenu 9 , školu za roditeljstvo pohađalo je 10\% ispitanica, $78 \%$ žena podoj je započelo sutradan, najveći broj je smatrao da je uspešno obučen za podoj u porodilištu. Nakon 7 dana po otpustu iz bolnice, $7 \%$ žena nije dojilo, najčešća prepreka za uspešno dojenje su ragade $(35 \%)$.

Zaključak Rezultati istraživanja ukazuju na potrebu većeg stepena edukacije budućih majki o značaju i pravilnim tehnikama dojenja. Potrebno je zdravstveno vaspitni rad sprovoditi na svim nivoima zdravstvene zeštite kako bi prisutnost prepreka za prirodnu ishranu bio minimalan.

Ključne reči: Dojenje, prirodna ishrana, ishrana, odojče. 